\title{
New life-cycle stages of Gymnodinium catenatum (Dinophyceae): laboratory and field observations
}

\author{
Rosa Isabel Figueroa ${ }^{1, *}$, Isabel Bravo ${ }^{2}$, Isabel Ramilo ${ }^{2}$, Yolanda Pazos ${ }^{3}$, \\ Angeles Moroño ${ }^{3}$ \\ ${ }^{1}$ Institut de Ciències del Mar (CSIC), 08003 Barcelona, Spain \\ ${ }^{2}$ Instituto Oceanográfico Vigo, Cabo Estai-Canido, 36200 Vigo, Spain \\ ${ }^{3}$ Instituto Tecnolóxico para o Control do Medio Mariño de Galicia, 36611 Vilaxoán, Pontevedra, Spain
}

\begin{abstract}
The chain-forming dinoflagellate Gymnodinium catenatum is responsible for outbreaks of paralytic shellfish poisoning (PSP); however, the relative importance of benthic-planktonic lifecycle transitions in the appearance of blooms of this species needs to be clarified. By coupling field and laboratory experiments, the present study is the first to analyze the dynamics of vegetative cells and sexual stages during a bloom of $G$. catenatum. In natural samples, the sexual stages of $G$. catenatum were associated with several different cellular behaviors and morphologies. This confirmed laboratory evidence for the reversibility of the species' sexual processes and for the ability of zygotes to either bypass or shorten the route to resting-cyst formation. Moreover, chains of up to 4 viable cysts with differing morphologies occurred and these have never been reported previously for this species. At least two of the cysts had reticulated surfaces, a feature related to sexual reproduction in previous studies; this observation suggests the involvement of sexual processes in mechanisms that cannot be explained by any known life cycle route depicted for this species. Morphological variability and abundance of the sexual stages during the bloom indicated the complexity of the G. catenatum sexual cycle and the important role of sexual reproduction in the ecological succession of this species. However, the lack of a dormancy period in the sexual resting stage (evidenced by the large number of germinated cysts in sediments sampled $3 \mathrm{mo}$ after the bloom) indicated that the advection of offshore populations shoreward, rather than 'seed beds', is the main mechanism explaining G. catenatum bloom formation in the Galician rías.
\end{abstract}

KEY WORDS: Dinophyceae - Encystment - Life-cycle stages · Gymnodinium catenatum • Galician rías Resale or republication not permitted without written consent of the publisher

\section{INTRODUCTION}

Gymnodinium catenatum Graham is an unarmored, cyst-forming dinoflagellate responsible for outbreaks of paralytic shellfish poisoning (PSP). Life-cycle changes allow populations of this toxic alga to alternately inhabit the benthos and the plankton, transitions that are essential in regulating the initiation and decline of dinoflagellate blooms and, thus, of PSP outbreaks (Anderson et al. 1983). Dinoflagellates comprise a diversified group of aquatic protists within which certain basic life-history traits appear to be largely conserved. Vegetative growth is by binary fission, but a sexual cycle has been demonstrated in an increasing number of species; in many cases the sexual process is related to formation of a resistant stage in which a so-called 'resting cyst' is formed (Beam \& Himes 1980, Pfiester 1989). The common sexual cycle begins with the fusion of haploid gametes to produce a diploid zygote (planozygote) that remains motile for variable periods of time before sinking to the bottom and encysting. The cyst represents a dormant phase, which is followed by germination. Meiosis is thought to occur in the germlings (planomeiocyte), returning the offspring to the haploid vegetative state.

Knowledge of the specific life-history characteristics of many dinoflagellates is essential for reliable species identification (since some life-cycle stages in a single species are sufficiently different that they have been assigned to different taxa) as well as the ability to 
understand and forecast the onset and evolution of bloom events. This knowledge also provides insight into the genetic diversity and structure of dinoflagellates.

Several recent studies suggest that, in cyst-forming dinoflagellate species, sexual reproduction is independent of resting-cyst formation. For example, under culture conditions, motile planozygotes divide and produce motile cells (Uchida et al. 1996, Figueroa \& Bravo 2005a,b, Figueroa et al. 2006a, 2007). Additionally, planozygotes in these culture conditions may develop into temporal or resting cysts (Figueroa \& Bravo 2005b, Figueroa et al. 2006a,b), fusing gamete pairs can divide before the cytoplasmic fusion is completed, and an asexual resting cyst has been described in Scrippsiella hangoei (Kremp \& Parrow 2006). These observations contribute to elucidating genetic structure and the capacity for adaptation in dinoflagellate populations, assuming that the potential for meiosis (i.e. sexual recombination) can be demonstrated at each of these lifecycle stages and not only at resting-cyst formation, as in cultures of Alexandrium minutum (Figueroa et al. 2007). Nonetheless, due to the difficulty in differentiating sexual from vegetative stages, the dinoflagellate life cycle has not been studied in natural samples but rather through culture experiments. Thus, a key question remains unanswered: Are the behaviors induced by culture conditions or are they also common cellular responses to the different environmental conditions found in nature?

The sexual cycle of Gymnodinium catenatum features several intriguing components; for example, the resting cyst of this species does not undergo a true dormancy period but usually germinates within a period of 15 d following cyst formation (Blackburn et al. 2001, Figueroa et al. 2006a), even under dark conditions (Bravo \& Anderson 1994). Since prior formation of a resting cyst may not be necessary for meiosis (Figueroa et al. 2006a), and long-term survival is also not assured by sexual cysts, the role of this stage of the life-cycle strategy is difficult to discern, given that temporary asexual cysts may be produced instead by a physiologically less costly process. In addition, sexual compatibility involves a complex heterothallic mating-type system (Blackburn et al. 2001), which includes strains with and without the ability to self-fertilize (Figueroa 2005).

Gymnodinium catenatum blooms have been reported repeatedly in distinct and widely separated regions along the western and southern coasts of the Iberian Peninsula and in the Atlantic coastal waters off northern Africa (Hallegraeff \& Fraga 1998). Off the Spanish Atlantic coast (the region of interest in the present study) the initial phase of G. catenatum blooms has been attributed to alongshore transport of offshore populations (Fraga et al. 1988, 1993, Sardo et al. 2001).
Toxic episodes caused by this species in northern Iberian Atlantic waters frequently occur a few days after similar episodes to the south. Accordingly, there is a hypothesis that blooms in the north are transported from those in the south by the Iberian Poleward Current (IPC), which flows northwards on the shelf slope off the west coast of Iberia (Fraga et al. 1993, Fraga 1996). However, Crespo \& Figueiras (2007) did not find evidence for the IPC-associated northward transport of Gymnodinium catenatum populations. Instead, these authors suggest that northward spreading was related to an interaction between the IPC, which causes the accumulation of coastal populations on the shelf, and microplankton succession, which follows a northward evolution and determines species composition. Furthermore, Sordo et al. (2001) suggest that G. catenatum populations are northwardly advected by an inshore northward current that has been detected following the coastline between Porto (Portugal) and the Galician rías.

Cysts of Gymnodinium catenatum have also been reported in sediments from coastal waters off the western Iberian Peninsula (Bravo \& Ramilo 1999), and other observations supported the hypothesis that cysts are the 'seeds' that inoculate algal blooms in this part of the region (Figueiras \& Pazos 1991).

The objective of the present study was to clarify the role of sexual reproduction in Gymnodinium catenatum blooms. To this end, we focused on the appearance of the sexual stages of this species from the onset to the end of the bloom and were able to obtain new, field-based information showing the existence of unknown life cycle stages and complex behaviours. Data on cyst germination are also presented. We discuss cellular behaviors associated with the naturally formed sexual stages in relation to those previously recorded under induced culture conditions.

\section{MATERIALS AND METHODS}

Study area. The Rías Baixas of Galicia are 4 bays on the NW Iberian Peninsula (Fig. 1) where harmful algal blooms of dinoflagellates are common (see for example Fraga 1984, Fraga et al. 1984). Intense upwelling events occur along this coast from April through October as part of the general upwelling system of the eastern North Atlantic (Fraga 1981, Fiuza 1983). The correlation between wind stress and coastal upwelling intensity is well-documented. Dominant northerly winds during the summer drive the surface waters offshore, injecting deeper waters into the Galician rías. When the winds change in autumn to southerly, the warmed offshore surface water moves towards the coast and downwelling areas are created in the mouths 


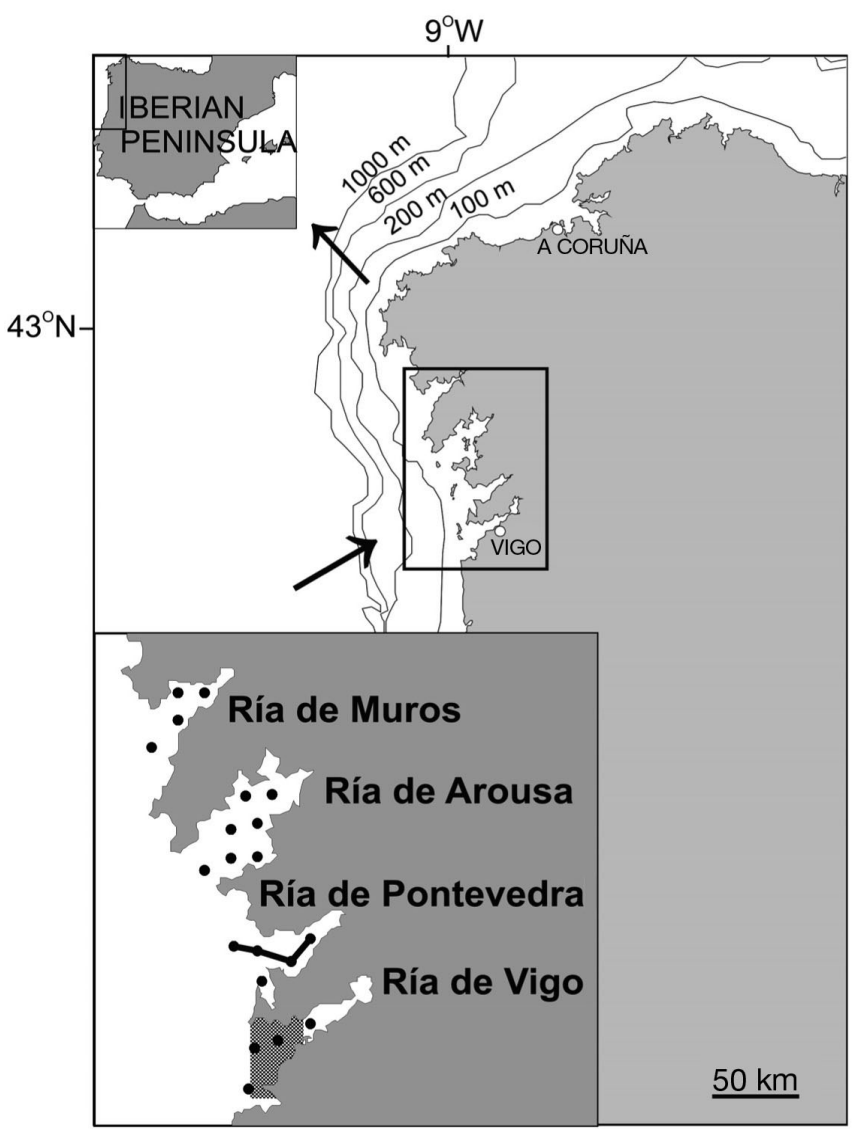

Fig. 1. Study area and location of the sampling stations in the Rías Baixas, Atlantic Spain. Hatched area in the Ría de Vigo shows where cyst distribution was studied. Continuous line in Ría de Pontevedra joins stations whose temperature distribution is represented in Fig. 3

of the rías (Otto 1975, Fraga 1981). This downwelling process is thought to be favorable for the development of chain-forming dinoflagellate blooms made up of species such as Gymnodinium catenatum (Fraga et al. 1988).

Hydrographic data and phytoplankton sampling. Upwelling indexes were calculated using wind speed and directional data measured every $6 \mathrm{~h}$ at a station located at $43^{\circ} \mathrm{N} 11^{\circ} \mathrm{W}$ in the eastern Atlantic Ocean (Lavin et al. 1991). The upwelling index estimates the Ekman offshore transport of surface water along a transect parallel to the shoreline. The phytoplankton and physical data were collected within the framework of the Phytoplankton Monitoring Program carried out each year in the Galician rías by the Technological Institute for Marine Environment Control of Xunta de Galicia. Our study was performed during November and December 2005, when the Gymnodinium catenatum bloom in the area reached maximal cell density. Phytoplankton cell concentrations were estimated and temperature and salinity were measured weekly at 25 stations along the western Galician coast (Fig. 1). Temperature and salinity profiles were obtained using a CTD Seabird 25. Integrated samples were taken using a pipe sampler (Lindahl 1986) from each station at depths of $0-5,5-10$, and 10-15 m. Water subsamples $(25 \mathrm{ml})$ from each layer were immediately fixed with Lugol's iodine solution (Throndse 1978). The number of $G$. catenatum cells in different life-cycle stages (vegetative cells, fusing gametes, planozygotes, cysts) were counted in the fixed samples using the Utermöhl method. Vegetative cells were easily identified by their chain-forming characteristics. Individual vegetative cells and planozygotes were separated by size and the presence of strongly Lugol's-stained starch granules. Cells in the process of fusion were distinguished by their $0^{\circ}$ to $90^{\circ}$ orientation to one another, following the criteria illustrated by Figueroa et al. (2006a).

Isolation of sexual stages and germination studies. Live cells of different sexual stages (fusing gametes, planozygotes, and resting cysts) were isolated from the samples at 3 different times during the bloom (November 28, December 5 and December 19, 2005). We selected old planozygotes to avoid confusion with planomeiocytes (planozygotes that undergo encystment prior to division), which are similarly biflagellate but smaller and with lighter coloration (Figueroa et al. 2006a). The behaviour of the motile zygotes was studied in planozygotes $(\mathrm{n}=100)$ individually placed in tissue-culture plates (Iwaki, $6.4 \mathrm{~mm}$ diameter) filled with $300 \mu \mathrm{l}$ of L1 medium (Guillard \& Hargraves 1993), and checked every second day for $35 \mathrm{~d}$.

The following parameters were estimated from the isolated planozygotes, which were either encysted or divided:

- Division percentage: ratio of dividing to encysting planozygotes

- Germination: excystment was defined as complete emergence of the protoplast from the cyst, even when the germling remained non motile (Anderson \& Wall 1978). Germination success was calculated as the ratio of cumulative excystment over $35 \mathrm{~d}$ to the total number of cysts isolated

- Minimum dormancy period: days from planozygote encystment to cyst germination

- Offspring viability: cyst progeny that had divided beyond the 8-cell stage were considered viable, since this stage represents 1 successful round of mitotic division following meiosis (Blackburn et al. 1989).

Nuclear staining. Cells were stained with 1:100 SYBR green in PBS 0.01M pH7 for $30 \mathrm{~min}$, washed in PBS and observed in an epifluorescence microscope at $497 \mathrm{~nm}$. Photographs were taken using a CANON EOS-D60 digital camera. 
Sediment sampling and cyst counting. Sediments were sampled in March 2006 at 19 stations in the Ría de Vigo, Spain. The sampling stations were regularly distributed in the area (Fig. 1). Cylinders measuring $20 \times 3 \mathrm{~cm}$ (length $\times$ diameter) were inserted into sediment collected with a box-corer. Samples were stored in the dark at $4{ }^{\circ} \mathrm{C}_{i}$ most samples were processed $1 \mathrm{wk}$ after sampling. The first step was to siphon off the water without disturbing the sediment interface. Profiles were then cut at $1 \mathrm{~cm}$ intervals to quantify the concentration of cysts in the upper $6 \mathrm{~cm}$. The sediment was sieved and a density gradient was established following the method of Bravo et al. (2006). Gymnodinium catenatum cysts were counted from $3 \mathrm{ml}$ subsamples in an Üthermol sedimentation chamber using a Zeiss Axiovert 135 inverted microscope at $400 \times$ magnification. The cysts were identified by their brown color, the presence of a microreticulate wall and their size (Anderson et al. 1988, Bravo \& Ramilo 1999).

Statistical analyses. Scheffé's post hoc test was applied following ANOVA using Statistica V.6 program (Statsoft, 2001). When the overall ANOVA $F$ statistic is significant, Scheffé's procedure can be used to evaluate all a posteriori means contrasts (not only pairwise comparisons). Scheffé's procedure uses the $F$ sampling distribution and, like ANOVA, is robust when data are normally distributed and variance is heterogeneous.
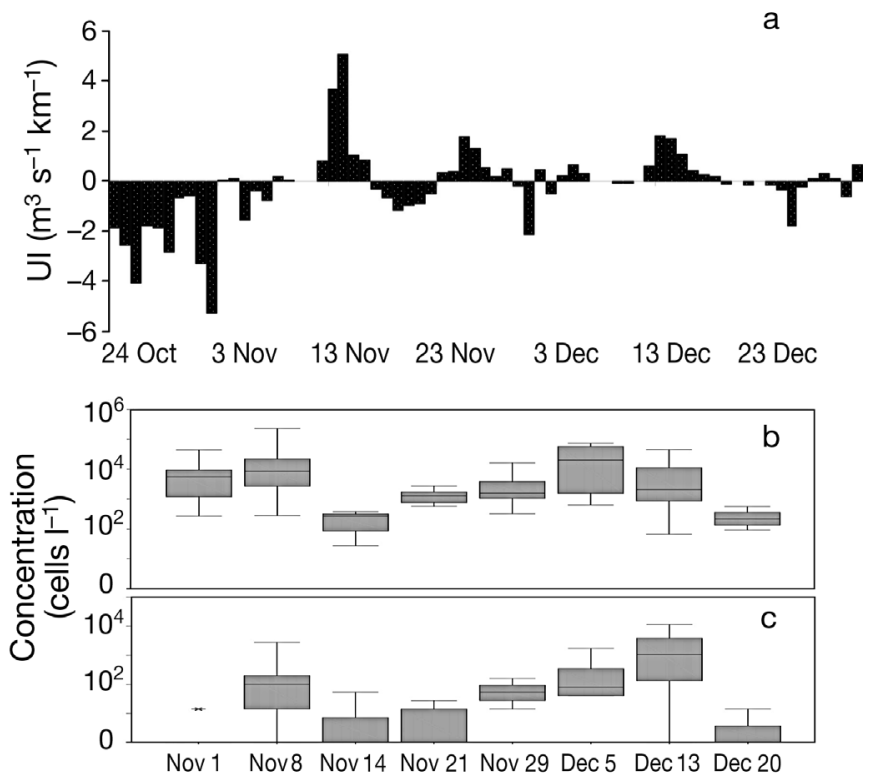

Fig. 2. Temporal distribution of (a) upwelling index (UI), (b) vegetative cell and (c) planozygote concentrations of Gymnodinium catenatum during the study period in 2005. Positive and negative values of UI indicate favorable conditions for upwelling and downwelling, respectively. (b) \& (c) show means and interquartile ranges for data from all stations for each date

\section{RESULTS}

\section{Bloom development}

In the period from October 24 through the end of December 2005, vegetative cell concentrations of Gymnodinium catenatum peaked twice (Fig. 2). The first peak occurred on November 8 , on which date

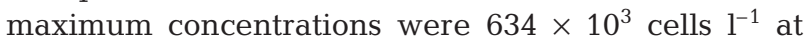
Ría de Muros and $143 \times 10^{3}$ cells $^{-1}$ at Ría de Pontevedra (see Fig. 1 for locations). The second peak occurred on December 13 at Ría de Pontevedra, when concentrations were as high as $92 \times 10^{3}$ cells $\mathrm{l}^{-1}$. These 2 peaks were associated with different oceanographic conditions. From the middle of October until November 8, upwelling indexes were negative, whereas from that date until the end of December several alternating upwelling and downwelling events occurred (Fig. 2). The different upwelling/ downwelling conditions were reflected in differences in water column structure during each period. Warmer surface water from offshore moved into the rías during relaxation of the upwelling, producing a temperature reversal in the water column on November 8 (Fig. 3b). Temperatures were $>16.5^{\circ} \mathrm{C}$ in the rías during this phase of the bloom. In contrast, the temperature of deep cold water was ca. $13.5^{\circ} \mathrm{C}$ on December 14, and these conditions persisted in all water columns until the end of the month (Fig. 3d).
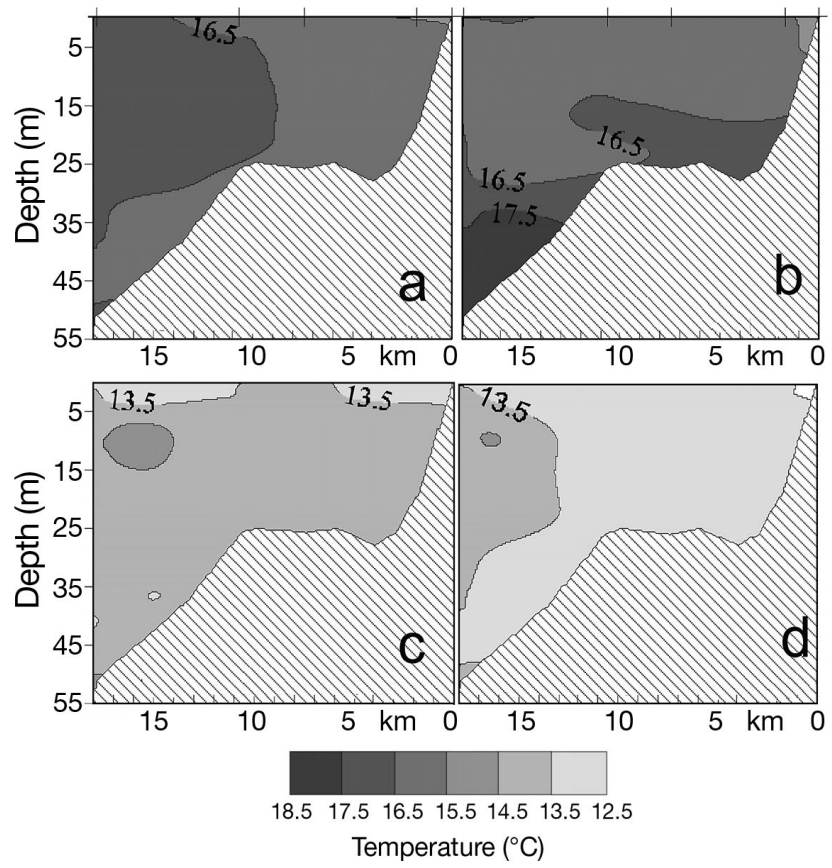

Fig. 3. Water temperature distribution at Ría de Pontevedra on (a) November 1, (b) November 8, (c) November 14 and (d) December 26, 2005. See Fig. 1 for station locations 

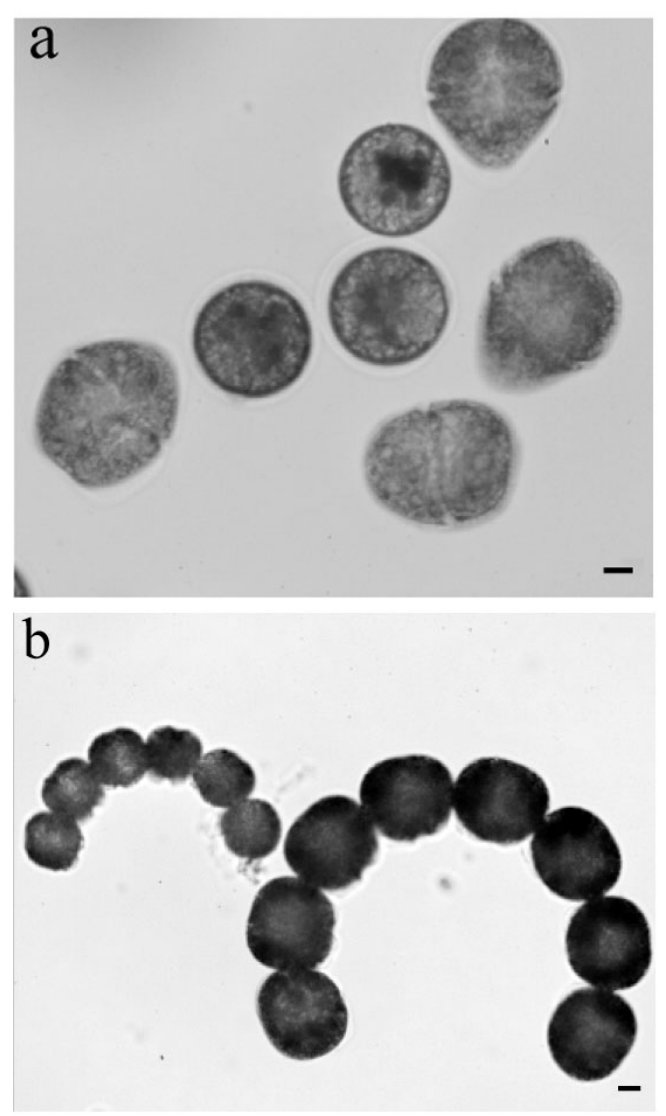

Fig. 4. Gymnodinium catenatum. Light micrographs of wild samples. (a) Mass encystment of planozygotes, (b) size variation in vegetative chains after Lugol's staining. Scale bars $=10 \mu \mathrm{m}$

\section{Life-cycle stages in living and Lugol's-fixed samples}

In addition to vegetative cells, sexual stages of Gymnodinium catenatum were clearly visible in samples of living cells. An example of numerous zygotes forming resting cysts is shown in Fig. 4 a.

\section{Vegetative cells}

Most vegetative chains comprised 2 to 16 cells, and cell sizes in the chains varied greatly (Fig. 4b). Table 1 shows the mean cell sizes in the chains during different periods of the bloom. Mean size differences between the first (November until December 5) and late (December 13 to 20) phases of the bloom were significant (Table 1). Small and large chains of cells were isolated and both yielded cultures of identical morphology that clearly corresponded to Gymnodinium catenatum as described by Hallegraeff et al. (1991).
Fusing gamete pairs

Cells in the process of fusion were joined to one another at angles of 0 to $90^{\circ}$ (Blackburn et al. 1989, Figueroa et al. 2006a) (Fig. 5a,b). The presence of gametes was confirmed by nuclear staining, since the nuclei of gametes are parallel (Fig. 5a), whereas those of vegetative divisions are arranged in a zig-zag pattern (Blackburn et al. 1989).

\section{Planozygotes}

Planozygotes were longitudinally biflagellate and had flattened apices, which is consistent with the descriptions of Blackburn et al. (1989) and Figueroa et al. (2006a). The size of living planozygotes in the bloom ( $\mathrm{n}=23$ ) (Fig. 5c) ranged between 53 and $84 \mu \mathrm{m}$ in length, and 31 and $59 \mu \mathrm{m}$ in width. Lugol's-fixed planozygotes stained darker than both vegetative cells and gametes (compare Fig. 5d with Lugol's-fixed gametes in Fig. 5a,b). Planozygotes (mean \pm SD, $59 \pm 7 \mu \mathrm{m}$ long, $53 \pm 7 \mu \mathrm{m}$ wide) were also larger than individual vegetative cells ( $39 \pm 8 \mu \mathrm{m}$ long, $38 \pm 7 \mu \mathrm{m}$ wide).

\section{Resting cysts}

Microreticulate resting cysts (Fig. 5e) were identified following the description of Anderson et al. (1988). Further confirmation was provided by the reticulation pattern of the empty cysts after germination (Fig. 5f,g) and by germling identification (Fig. 5h). No empty cysts were observed in water samples. Sizes of cysts obtained from sediments were very similar to those of cysts collected in the water (mean $\pm \mathrm{SD}, 47 \pm 4.5 \mu \mathrm{m}$, $\mathrm{n}=23$ and $48 \pm 5.3, \mathrm{n}=160$, respectively).

Two life-cycle stages not previously described in natural samples or in cultures were observed in samples isolated on November 28 and December 5 as follows:

Dividing fusing gamete pairs. Pairs of fusing gametes in which one cell was undergoing vegetative division before completion of the conjugation process (Fig. 6a) were recognized by the specific positioning of the cingula (Figueroa et al. 2006a). The conjugating pairs were joined at the level of the cingula, which were oriented at about $90^{\circ}$.

Chains of cyst-like stages. We also identified and isolated chains made up of vegetative and cyst-like stages (Fig. 6b) and chains made up of 2, 3, or 4 cyst-like forms $(n=6)$ (Fig. 6c-e). Four main points summarize our observations of these stages after germination:

- All cyst-like chains isolated were viable, and typical Gymnodinium catenatum cells able to generate new cultures were produced by all germinations. 
Table 1. Gymnodinium catenatum. Average size $(\mu \mathrm{m})$ of cells at different time periods of the bloom. ${ }^{*}$ Statistically different between dates listed (numbered in parentheses) ( $p<0.05$, Scheffé's test)

\begin{tabular}{|lrlrl|}
\hline Date (2005) & N & Mean & SD & SE \\
\hline Length & & & & \\
Nov 8 (1) & 156 & $32.7^{* 3,4,5,6}$ & 3.9 & 0.3 \\
Nov 21 (2) & 270 & $33.4^{* 3,4,5,6}$ & 4.3 & 0.3 \\
Nov 28 (3) & 415 & $34.9^{* 1,2,5,6}$ & 4.1 & 0.2 \\
Dec 5 (4) & 586 & $34.7^{* 1,2,5,6}$ & 4.1 & 0.2 \\
Dec 13 (5) & 516 & $36.7^{* 1,2,3,4}$ & 4.9 & 0.2 \\
Dec 20 (6) & 93 & $37.4^{* 1,2,3,4}$ & 6.3 & 0.6 \\
Width & & & & \\
Nov 8 (1) & 156 & $34.9^{* 5,6}$ & 5.3 & 0.4 \\
Nov 21 (2) & 270 & $34.9^{* 5,6}$ & 5.0 & 0.3 \\
Nov 28 (3) & 415 & $35.8^{* 5,6}$ & 4.8 & 0.2 \\
Dec 5 (4) & 586 & $35.8^{* 5,6}$ & 4.7 & 0.2 \\
Dec 13 (5) & 516 & $37.9^{* 1,2,3,4}$ & 5.5 & 0.2 \\
Dec 20 (6) & 93 & $39.3^{* 1,2,3,4}$ & 6.2 & 0.6 \\
\hline
\end{tabular}

- We observed synchronous (when the cysts of 1 chain germinated simultaneously) and asynchronous (when the cysts of 1 chain germinated at different times) germinations (Fig. 6f).

- Reticulated and non-reticulated empty cysts remained after germination (Fig. 6f-h).

- The maximum number of cysts observed per chain was 4, and the maximum number of reticulated cysts per chain was 2 ( 8 chains observed in total: 5 formed by 2 cysts, 2 formed by 3 cysts and 1 formed by 4 cysts).

\section{Occurrence of sexual reproduction during the bloom}

Only a few planozygotes were detected on November 1 at 3 stations in Ría de Pontevedra and Ría de Vigo. The number of planozygotes subsequently increased in all regions, particularly in the southern rías (up to $2.8 \times 10^{3}$ cells $\mathrm{l}^{-1}$ ), coinciding with the peak in vegetative cell number on November 8 (Fig. 2c). The highest concentrations of planozygotes $\left(11.5 \times 10^{3}\right.$ cells $\mathrm{l}^{-1}$ ) occurred on December 13 at Ría de Pontevedra, following the second peak of vegetative cells on December 5 (Fig. 2c). The sexual reproduction fractions (fraction of cells undergoing sexual reproduction) in each of the bloom periods were 0.03 in November and 0.23 in December. Planozygote distribution varied among rías, with a smaller proportion of planozygotes occurring in Ría de Muros concurrently with the highest vegetative cell concentration at that site on November 8 (Fig. 2b,c). The distribution of cysts and fusing gametes tracked the planozygote trend (although at much lower cell concentrations). The characteristic microreticulate cyst of Gymnodinium catenatum was rarely
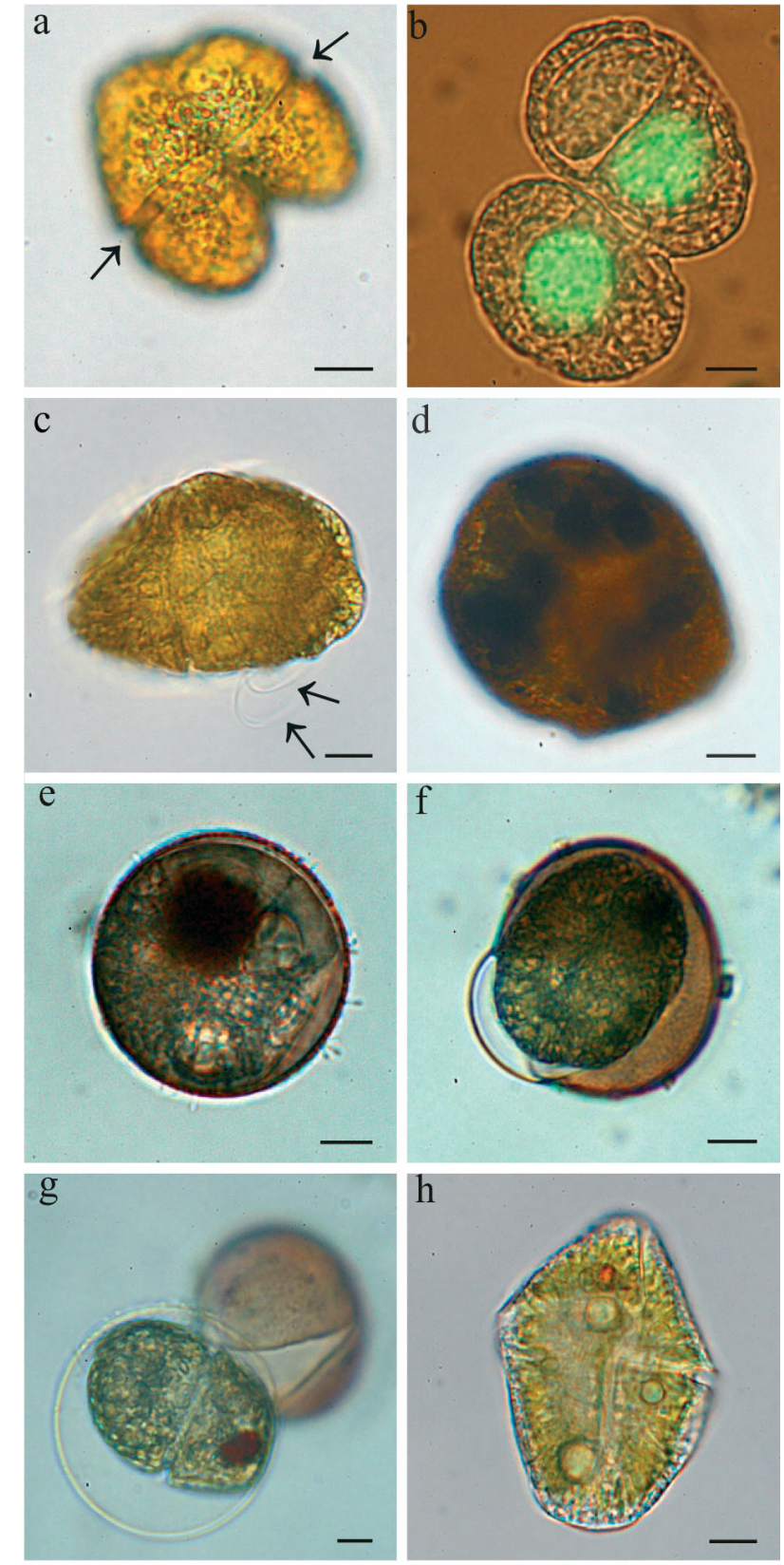

Fig. 5. Gymnodinium catenatum. Light micrographs of sexual stages. (a) Lugol's-fixed fusing gamete pair attached at the cingulum (arrows), (b) nuclear position after SYBR green staining, (c) live planozygote with 2 longitudinal flagella (arrows), (d) planozygote after Lugol's fixation, which produces a deep brown color, (e) dormant resting cysts, (f) germinating cyst, (g) newly formed planomeiocyte still surrounded by a membranous layer, (h) a planomeiocyte $48 \mathrm{~h}$ old. Scale bars $=10 \mu \mathrm{m}$

seen in the water column except during bloom peaks when concentration maxima in Ría de Pontevedra reached 80 and 373 cysts $1^{-1}$ in November and on December 13, respectively. These peaks coincided with maximum planozygote concentrations. 

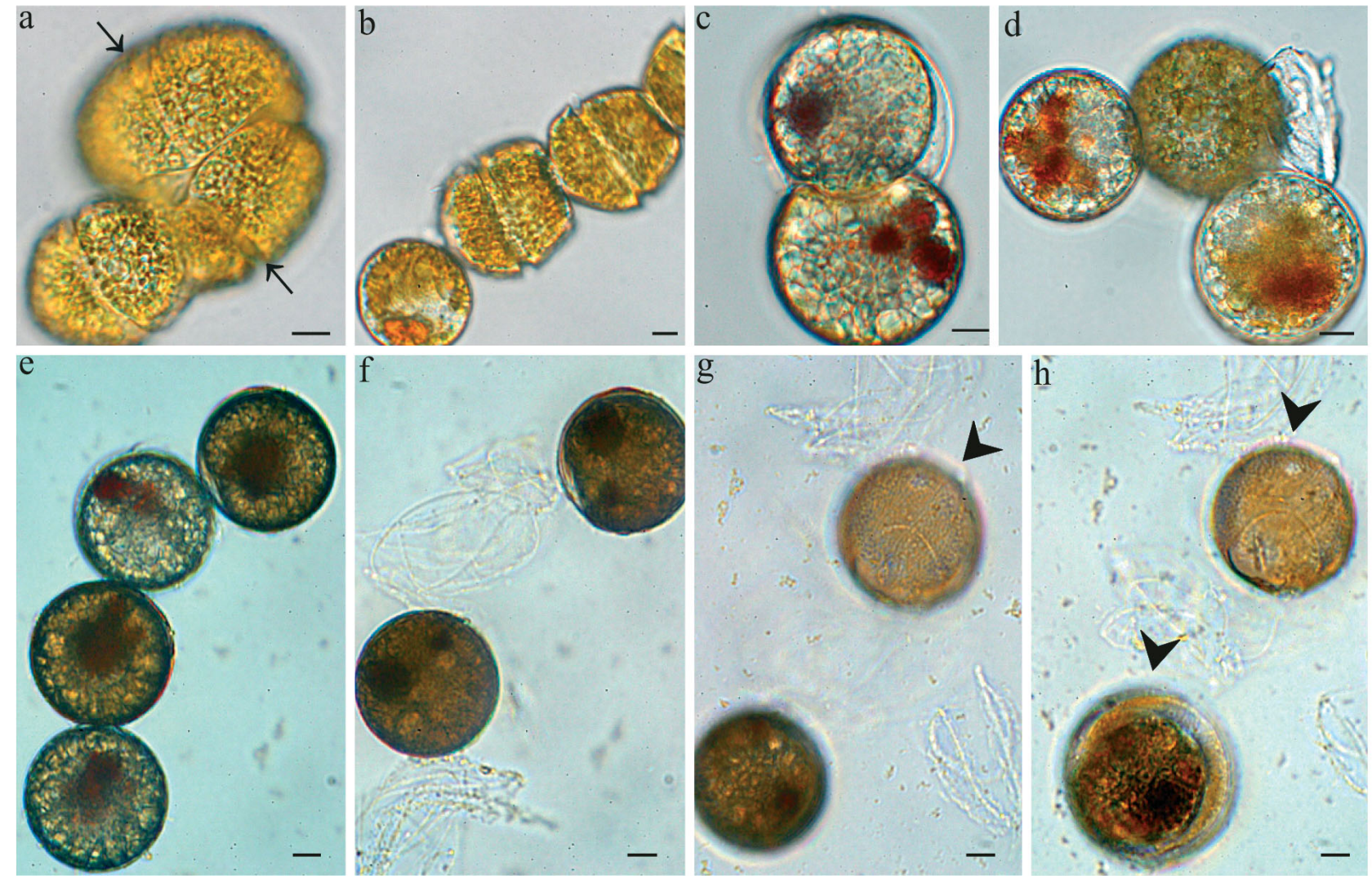

Fig. 6. Gymnodinium catenatum. Light micrographs of sexual stages. (a) Dividing fusing gamete pair with cingular attachment (arrows), (b) chain with 1 cell undergoing cyst formation, (c) 2-cyst chain, (d) 3-cyst chain, (e) 4-cyst chain, (f) synchronous germination of 2 cysts with shed, thin envelopes, $(g, h)$ asynchronous germination of 2 cysts formerly part of the same chain, with 2 shed, reticulated empty cysts (arrowheads). Scale bars $=10 \mu \mathrm{m}$

\section{Cyst concentrations in the sediment after the bloom}

The distribution of cysts in sediments was studied only in the external part of Ría de Vigo (Fig. 1). Maximum concentrations occurred in surface sediments $(0-1 \mathrm{~cm})$, with the exception of 1 station where the maximum occurred in the second depth interval (1-2 cm). Surface sediments contained an average $( \pm \mathrm{SD})$ of $263 \pm 243$ cysts $\mathrm{cm}^{-3}$ wet sediment, whereas in the first $4 \mathrm{~cm}$ of sediment, the mean cyst concentration was 109 cysts $\mathrm{cm}^{-3}$ wet sediment. This value corresponds to an estimated 436 cysts $\mathrm{cm}^{-2}$ in the uppermost
$5 \mathrm{~cm}$ of sediment in the area we studied. Empty and live cysts were present in the samples. The percentage of empty cysts depended on the sample (mean $=59 \pm$ $23 \%)$.

\section{Isolation of sexual stages and germination study}

The isolated planozygotes followed one of 2 lifecycle routes: division or encystment. Only $12.5 \%$ of the planozygotes underwent division; those remaining encysted. Cyst size, dormancy period, germinability,

Table 2. Gymnodinium catenatum. Characteristics of cysts formed by wild planozygotes isolated at different bloom periods. *Statistically different between dates listed (numbered in parentheses) ( $p<0.05$, Scheffé's test)

\begin{tabular}{|lccccc|}
\hline Date (2005) & $\mathrm{N}$ & $\begin{array}{c}\text { Cyst size } \\
(\mu \mathrm{m}, \text { mean } \pm \mathrm{SD})\end{array}$ & $\begin{array}{c}\text { Dormancy period } \\
(\mathrm{d}, \text { mean } \pm \mathrm{SD})\end{array}$ & $\begin{array}{c}\text { Germinability } \\
(\%)\end{array}$ & $\begin{array}{c}\text { Offspring } \\
\text { viability }(\%)\end{array}$ \\
\hline Nov 8 (1) & 26 & $45.6 \pm 5.3$ & $5.8 \pm 1.7$ & 90.5 & 95 \\
Dec 5 (2) & 47 & $44.2 \pm 5.1$ & $7.7 \pm 1.9$ & 92.3 & 83 \\
Dec 20 (3) & 49 & $50.7 \pm 5.3^{* 1,2}$ & $8.1 \pm 2.7^{* 1}$ & $60.5^{* 1}$ & $55^{* 1,2}$ \\
\hline
\end{tabular}


and offspring viability were analyzed for the cysts that were formed. Significant differences among time periods occurred for all characteristics (Table 2). Cyst sizes ranged from 35 to $59 \mu \mathrm{m}$, with the larger cysts (mean \pm $\mathrm{SD}, 50.7 \pm 5.3 \mu \mathrm{m}$ ) formed on December 19 (Table 2). Dormancy period, germinability, and offspring viability differed between the first and the last day of planozygote isolation. The dormancy period of cysts obtained from the planozygotes isolated on the last day (8 d) was significantly longer than that of planozygotes isolated at the end of the first week of November $(6 \mathrm{~d})$ (Table 2), and the standard deviation was considerably larger. Germinability and viability of the offspring followed reverse trends. Germinability of cysts derived from planozygotes on the last day of isolation was only $60.5 \%$ compared to $>90 \%$ from cysts that had formed from planozygotes obtained on the other dates (Table 2). Additionally, the viability of germlings obtained from late December cysts was almost $50 \%$ lower than that of the germling from cysts isolated on the first day (Table 2). In contrast, $90 \%$ of the cysts obtained from sediment underwent germination.

\section{DISCUSSION}

To our knowledge, this is the first study of sexual reproduction in Gymnodinium catenatum based on field samples collected during bloom conditions. The difficulty of these kinds of studies is well-known; sexual stages of dinoflagellates are extremely difficult to identify and differentiate from vegetative cells. We based our study upon information gathered from earlier experiments with culture material, in which individually isolated sexual stages were monitored and characterized (Blackburn et al. 1989, Figueroa et al. 2006a), and upon characteristic features of Lugol's stained zygotes. The identification of different life-history stages allowed us to develop a more comprehensive understanding of the relationship between bloom dynamics in G. catenatum and environmental conditions.

\section{Reproductive process characteristics}

Although culture conditions are claimed to provoke unusual behaviors in the organism under study, our results suggest that studies of sexual reproduction in nature extend the conclusions drawn from observations of dinoflagellate cultures, with important consequences for interpreting the dynamics and genetic structures of blooms. In the last decade, there has been accumulating evidence that sexual reproduction and resting-cyst formation are not necessarily linked pro- cesses. Indeed, the division capacity of planozygotes has been confirmed in several species, such as Scrippsiella trochoidea (Stein) Loeblich (Uchida 1991), Gyrodinium instriatum Freudenthal \& Lee (Uchida et al 1996), Gymnodinium nolleri Ellegaard \& Moestrup (Figueroa \& Bravo 2005a), Gymnodinium catenatum Graham (Figueroa et al. 2006a), Lingulodinium polyedrum (Stein) Dodge (Figueroa \& Bravo 2005b), and Alexandrium minutum Halim (Figueroa et al. 2007). These studies suggest that the formation and fate of different life-cycle stages are determined by many variables including genetic, nutritional and cell density factors, and that the benefits of sexual recombination can be achieved by routes that are faster than longterm encystment. For example, planozygote division is triggered in G. catenatum when nutrients are added to the deficient medium in which they were formed, suggesting that the new conditions obviate the need for encystment (Figueroa et al. 2006a). These authors described identical nuclear morphologies in dividing planozygotes and planomeiocytes (planozygotes which undergo encystment prior to division), a finding which implies that meiosis is associated not only with cyst formation but also with planozygote division. In support of this assertion, inheritance studies have recently linked this route to meiosis (Figueroa et al. 2007). Furthermore, Figueroa et al. (2006a) were able to demonstrate division of fusing gamete pairs before the end of syngamy. Some of the fusing gamete pairs did not form planozygotes and, when a sudden nutritional change was made in the culture medium, the gamete pairs underwent a division process before completing cytoplasmic fusion. These observations were explained as a versatile behavior of sexual stages of $G$. catenatum, i.e. one that allows bypassing or shortening the resting-cyst formation route in response to external conditions becoming benign or much more adverse, respectively.

We confirmed these behaviors by observations of both the division capacity of Gymnodinium catenatum wild planozygotes and fusing gamete pairs isolated from a bloom. These facts, as well as other previously unreported aspects of G. catenatum's life cycle, such as the presence of chains of cyst-like stages, support the conclusion that sexual reproduction is not occasional and unidirectional, but rather a frequent and flexible route. The existence of this sexual flexibility might have important implications. In earlier studies (Blackburn et al. 1989, 2001 Figueroa et al. 2006a), reticulate walls were only observed after sexual fusion. If this is the case, then the way in which these chains of cystlike stages are formed is yet to be resolved. Two main mechanisms can be hypothesized:

(1) The chains are formed by fusion, either of gametes with vegetative chains, between 2 different chains, or 


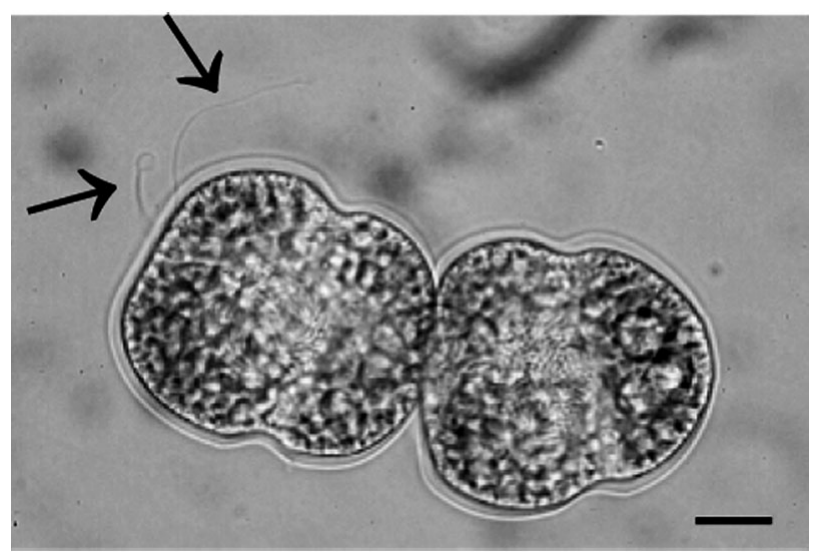

Fig. 7. Two-celled chain formed by planomeiocyte division; note the posterior cell has 2 longitudinal flagella (arrows). Scale bars $=10 \mu \mathrm{m}$

within 1 chain. This last mechanism would be similar to the formation of cyst chains described for the myxobacterium Chondromices thaxteri (Faull 1916), in which there is fusion between neighboring cells.

(2) They are formed by the encystment of diploid cells (planozygote or planomeiocyte) after the first meiotic division. In Gymnodinium catenatum, zygotes are thought to undergo a 2-step meiosis (Figueroa et al. 2006a) since mobile zygotes and planomeiocytes yield a biflagellated 2-celled chain after the first meiotic division (Fig. 7); later, in the second meiotic division, this chain gives rise to a 4-celled chain of longitudinally monoflagellated cells. Thus, cells in the first 2 chains might be diploid (2n-2n), whereas the ensuing 4 -cell chain should be haploid (n-n-n-n). Since diploid cells are the only ones linked to the formation of reticulated cysts in this species (Blackburn et al. 1989, Figueroa et al. 2006a), the encystment of a 2-celled chain may be a plausible explanation. How a 4-celled chain of cysts could be formed in this case is unknown, but the maximum number of reticulated cysts per chain observed in this study was 2 .

Evidence leading to acceptance of either of these hypotheses will force us to revise our concepts of 'gametes' or 'planozygotes' within the sexual reproduction of dinoflagellates.

\section{Resting-cyst formation and germination}

Samples containing live specimens obtained on 3 different occasions during the blooms provided us with large numbers of planozygotes that were easily recognizable by their color, size, shape and the presence of double longitudinal flagella. After their transfer to replete medium, $12.5 \%$ of the planozygotes divided, implying that this process, until now described uniquely in culture, also takes place in nature (although the percentage was significantly lower than that observed in culture) (Figueroa et al. 2006a). Figueroa et al. (2006a) observed division mainly in newly formed planozygotes $(<24 \mathrm{~h})$, which suggests that the capacity for division is lost over time. The present study focused on old planozygotes, which are darker, larger and have 2 longitudinal flagella, properties that make them easier to identify and thus allow correct isolation from a natural sample. Therefore, our data lead to the conclusion that old planozygotes lose their ability to divide. We also found that cyst viability decreases towards the end of the bloom. This is coupled with an increment in the size and dormancy period of the cysts formed by the isolated planozygotes. The size of cysts isolated from sediment samples ranged from 34 to $62 \mu \mathrm{m}$, and the viability of cysts smaller than $40 \mu \mathrm{m}$ was relatively low. According to our results, a size range of 40 to $50 \mu \mathrm{m}$ might be optimal for offspring survival.

\section{Consequences for population dynamic studies}

Seasonal blooms of Gymnodinium catenatum in Galician waters are thought to develop offshore and move to the Galician rías when a relaxation of the upwelling drives the bloom inshore (Fraga et al. 1988, Crespo et al. 2006). Since upwelling in this region is seasonal, the inshore occurrence of the blooms is related to the seasonality of upwelling. Different mechanisms have been proposed to explain the source of the blooms in the area: (1) vegetative cells are transported from the south by the IPC (Fraga 1996) or by an inshore northward current (Sordo et al 2001); (2) the IPC causes the accumulation of G. catenatum populations on the shelf and the species appears in the north simply as a consequence of latitudinal progress in microplankton succession (Crespo \& Figueiras 2007); (3) germination of resting cysts from the sediment is a source of blooms in the water column (Figueiras \& Pazos 1991, Crespo 2007).

Gymnodinium catenatum cysts are distributed among the sediments of the continental shelf (Hallegraeff \& Fraga 1998, Bravo \& Ramilo 1999). Our data confirm that the seeding of cysts occurs in these sediments during a bloom and probably extends to an even wider zone. However, the fact that only 3 mo after the bloom $59 \%$ of the cysts (on average) were empty implies that germination occurred during winter and spring, i.e. germination did not coincide with any bloom in the region or in the following months (data from Phytoplankton Monitoring Program). Bravo \& Ramilo (1999) also reported that the majority of cysts in the sediment after the 1993 bloom were empty, suggesting that $G$. catenatum resting cysts were not likely 
to seed subsequent blooms. These observations support the hypothesis that the blooms of G. catenatum in Galician rías are most likely caused by an inoculum derived from offshore vegetative populations. In addition, the above-described reproductive process and the short dormancy period together suggest that sexual reproduction in this dinoflagellate is frequent and independent of cyst formation, which is a fast recombination stage not related to long-term survival or seasonal germination cycles. Supporting this hypothesis is the high local genetic variability reported for G. catenatum strains from Galicia and the south of Spain (shown by RAPD analysis, Ordás et al. 2004). High genetic variability is known to increase the odds of survival in changing environments that are encountered in the wide geographic area where G. catenatum is found. Moreover, a contribution of germlings from cysts (at least to some extent) to growing offshore populations cannot be ruled out; these offshore populations may be introduced into the rías by hydrological events. Crespo (2007) suggested that vegetative cells arising from the germination of cysts in sediments of the rías are transported offshore during upwellings and introduced into the rías during autumn downwellings, such that the inshore appearance of blooms is independent of the IPC.

The highest abundance of sexual stages was associated with low temperatures measured in December, when a series of small upwellings occurred after a period of relaxation in November. Cysts of Gymnodinium catenatum were detected in the water column in 1986 during the most intensive bloom ever reported in the rías, which also coincided with a minimum water temperature (unpublished data from Phytoplankton Monitoring Program). Although there is no information on encystment factors for this species, temperature is known to affect the encystment of some dinoflagellate species (Anderson et al. 1985, Nagai et al. 2004).

Our data support the theory that cyst beds do not play a definitive role in the formation of blooms in the rías; instead, relationships between sexual reproduction and environmental conditions are probably important elements for the success of this harmful species. Further studies are needed to determine the factors inducing sexual reproduction in Gymnodinium catenatum and to confirm the role of temperature in its life cycle.

Acknowledgements. We thank P. Rial and A. Fernández-Villamarín, for technical assistance and the crew of the RV 'J. M. Navaz' for their help in sampling. This study was funded by the EU Project SEED (GOCE-CT-2005-003875) and the Xunta de Galicia Monitoring Program. R.I.F. was supported by a postdoctoral I3P contract from the Spanish Ministry of Education and Science.

\section{LITERATURE CITED}

Anderson DM, Wall D (1978) Potential importance of benthic cysts of Gonyaulax tamarensis and G. excavata in initiating toxic dinoflagellate blooms. J Phycol 14:224-234

Anderson DM, Chisholm SW, Watras CJ (1983) Importance of life cycle events in the population dynamics of Gonyaulax tamarensis. Mar Biol 76:179-183

Anderson DM, Coats DW, Tyler MA (1985) Encystment of the dinoflagellate Gyrodinium uncatenum: temperature and nutrient effects. J Phycol 21:200-206

Anderson DM, Jacobson DM, Bravo I, Wrenn JH (1988) The unique, microreticulate cyst of the naked dinoflagellate Gymnodinium catenatum. J Phycol 24:255-262

Beam CA, Himes M (1980) Sexuality and meiosis in dinoflagellates. In: Levandowsky IM, Hutner SH (eds) Biochemistry and physiology of Protozoa. Academic Press, New York, p 171-206

Blackburn SI, Hallegraeff GM, Bolch CJS (1989) Vegetative reproduction and sexual life cycle of the toxic dinoflagellate Gymnodinium catenatum. J Phycol 25:577-590

Blackburn SI, Bolch CJS, Haskard KA, Hallegraeff GM (2001) Reproductive compatibility among four global populations of the toxic dinoflagellate Gymnodinium catenatum (Dinophyceae). Phycologia 40:78-87

Bravo I, Anderson DM (1994) The effects of temperature, growth medium and darkness on excystment and growth of the toxic dinoflagellate Gymnodinium catenatum from northwest Spain. J Plankton Res 16:513-525

Bravo I, Ramilo I (1999) Distribution of microreticulate dinoflagellate cysts from the Galician and Portuguese coast. Sci Mar 63:45-50

Bravo I, Garcés E, Diogène J, Fraga S, Sampedro N, Figueroa RI (2006) Resting cysts of the toxigenic dinoflagellate genus Alexandrium in recent sediments from the Western Mediterranean coast, including first description of cysts of A. kutnerae and A. peruvianum. Eur J Phycol 41:293-302

Crespo BG (2007) Proliferaciones de dinoflagelados y procesos oceanográficos asociados en un sistema de afloramiento. Doctoral thesis, University of Vigo

Crespo BG, Figueiras FG (2007) A spring poleward current and its influence on microplankton assemblages and harmful dinoflagellates on the western Iberian coast. Harmful Algae 6:686-699

> Crespo BG, Figueiras FG, Porras P, Teixeira IG (2006) Downwelling and dominance of autochthonous dinoflagellates in the NW Iberian margin: the example of the Ría de Vigo. Harmful Algae 5:770-781

Faull JH (1916) Fommes officinalis (Vill.), a timber-destroying fungus. Trans R Can Inst 11:185-209

Figueiras FG, Pazos Y (1991) Hydrography and phytoplankton of the Ría de Vigo before and during a red tide of Gymnodinium catenatum Graham. J Plankton Res 13: 589-608

Figueroa RI (2005) The significance of sexuality and cyst formation in the life cycle of four marine dinoflagellate species. Doctoral thesis, University of Lund

Figueroa RI, Bravo I (2005a) A study of the sexual reproduction and determination of mating type of Gymnodinium nolleri (Dinophyceae) in culture. J Phycol 41:74-83

> Figueroa RI, Bravo I (2005b) Sexual reproduction and two different encystment strategies of Lingulodinium polyedrum (Dinophyceae) in culture. J Phycol 41:370-379

> Figueroa RI, Bravo I, Garcés E, Ramilo I (2006a) Nuclear features and nutrient effect on Gymnodinium catenatum (Dinophyceae) sexual stages. J Phycol 42:67-77

Figueroa RI, Rengefors K, Bravo I (2006b) Effects of parental 
factors and meiosis on sexual offspring of Gymnodinium nolleri (Dinophyceae). J Phycol 42:350-362

Figueroa RI, Garcés E, Bravo I (2007) Comparative study of the life cycles of Alexandrium tamutum and Alexandrium minutum (Gonyaulacales, Dinophyceae) in culture. J Phycol 43:1039-1053

Fiuza AFG (1983) Upwelling patterns off Portugal. I. In: Suess E, Thiede J (eds) Coastal upwelling: its sediment record. Part A. Responses of the sedimentary regime to present coastal upwelling. Plenum, New York, p 85-98

Fraga S (1981) Upwelling off the Galician coast, Northwest Spain. In: Richard FA (ed) Coastal upwelling. American Geophysical Union, Washington, DC, p 176-182

Fraga S (1984) El fitoplancton como fuente de toxicidad en las rías gallegas. In: Proceedings of the first seminar on Marine Science: The Galician Rías. Publicacións do Seminario de Estudos Galegos, p 209-215

Fraga S (1996) Wintering of Gymnodinium catenatum Graham (Dinophyceae) in Iberian Waters. In: Yasumoto $T$, Oshima Y, Fukuyo Y (eds) Harmful and toxic algal blooms. Intergovernmental Oceanographic Commission of UNESCO, Paris, p 211-214

Fraga S, Mariño J, Bravo I, Miranda A and others (1984) Red tides and shellfish poisoning in Galicia (NW Spain). ICES Special meeting on the causes, dynamics and effects of exceptional Marine Blooms and related Events, C:5

Fraga S, Anderson DM, Bravo I, Reguera B, Steidinger KA, Yentsch CM (1988) Influence of upwelling relaxation on dinoflagellates and shellfish toxicity in Ría de Vigo, Spain. Estuar Coast Shelf Sci 27:349-361

Fraga S, Bravo I, Reguera B (1993) Poleward surface current at the shelf break and blooms of Gymnodinium catenatum in Ría de Vigo (NW Spain). In: Smayda TJ, Shimizu Y (eds) Toxic phytoplankton blooms in the sea. Elsevier, Amsterdam, p 245-249

Guillard RRL, Hargraves PE (1993) Stichochrysis immobilis is a diatom, not a chrysophyte. Phycologia 32:234-236

Hallegraeff GM, Fraga S (1998) Bloom dynamics of the toxic dinoflagellate Gymnodinium catenatum, with emphasis on Tasmanian and Spanish coastal waters. In: Anderson DM, Cembella AD, Hallegraeff GM (eds) Physiological

Editorial responsibility: Klaus Jürgens, Rostock, Germany ecology of harmful algal blooms. Spinger-Verlag, Berlin, p 59-80

Hallegraeff GM, Nichols PD, Volkman JK, Blackburn SI, Everitt DA (1991) Pigments, fatty acids, and sterols of the toxic dinoflagellate Gymnodinium catenatum. J Phycol 27:591-599

Kremp A, Parrow M (2006) Evidence for asexual resting cysts in the life cycle of the marine peridinoid dinoflagellate, Scrippsiella hangoei. J Phycol 42:400-409

Lavin A, Díaz del Río G, Cabanas JM, Casas G (1991) Afloramiento en el Noroeste de la Península Ibérica. Índices de afloramiento para el punto $43^{\circ} \mathrm{N} 11^{\circ} \mathrm{W}$. Informes Técnicos del Instituto Español de Oceanografía 91:1-39

Lindahl O (1986) A dividable hose for phytoplankton sampling. Report No. C.M. 1986/L.:26, Annex 3. International Council for the exploration of the Sea, Copenhagen

Nagai S, Matsuyama Y, Oh S, Itakura S (2004) Effect of nutrients and temperature on encystment of the toxic dinoflagellate Alexandrium tamarense (Dinophyceae) isolated from Hiroshima Bay, Japan. Plankton Biol Ecol 51: 103-109

> Ordás MC, Fraga S, Franco JM, Ordás A, Figueras A (2004) Toxin and molecular analysis of Gymnodinium catenatum (Dinophyceae) strains from Galicia (NW Spain) and Andalucia (S Spain). J Plankton Res 26:341-349

Otto L (1975) Oceanography of the Ría de Arosa. Koninklijk Ned Meteorol Inst Mededelingen Verh 96

Pfiester LA (1989) Dinoflagellate sexuality. Int Rev Cytol 114:249-272

Sordo I, Barton ED, Cotos JM, Pazos Y (2001) An inshore poleward current in the NW of the Iberian Peninsula detected from satellite images, and its relation with $G$. catenatum and $D$. acuminata blooms in the Galician Rías. Estuar Coast Shelf Sci 53:787-799

Throndse J (1978) Preservation and storage. In: Sournia A (ed) Phytoplankton manual. UNESCO, Paris, p 69-74

Uchida T (1991) Sexual reproduction of Scrippsiella trochoidea isolated from Muroran Harbor Hokkaido. Nippon Suisan Gakkaishi/Bull Jpn Sci Fish 57:1215

> Uchida T, Matsuyama Y, Yamaguchi M, Honjo T (1996) The life cycle of Gyrodinium instriatum (Dinophyceae) in culture. Phycol Res 44:119-123

Submitted: November 5, 2007; Accepted: March 25, 2008 Proofs received from author(s): June 11, 2008 